\title{
The Influence of Personality and Chronotype on Distance Learning Willingness and Anxiety among Vocational High School Students in Turkey
}
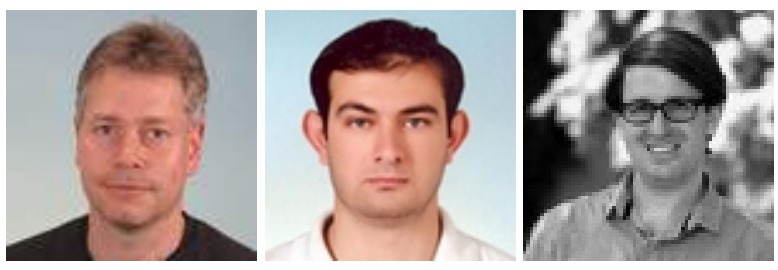

Christoph Randler1, Mehmet Barış Horzum², and Christian Vollmer ${ }^{1}$ ${ }^{1}$ Heidelberg EducationUniversity, Germany, ${ }^{2}$ Sakarya University, Turkey

\section{Abstract}

There are many studies related to distance learning. Willingness and anxiety are important variables for distance learning. Recent research has shown that anxiety and willingness towards distance learning are moderated by personality. This study sought to investigate whether distance learning willingness and distance learning anxiety are associated with age, gender, occupation, chronotype and personality in a Turkish vocational high school students sample. Two measures of individual differences were implemented: chronotype (morningness/eveningness preference) and BIG-5 dimensions (agreeableness, conscientiousness, extraversion, neuroticism, and openness). Seven hundred and sixty-nine vocational high school students from Turkey filled out a self-administered questionnaire. Evening types, older, and female students had higher distance learning willingness scores than morning types, younger, and male students. No significant difference was found between chronotype groups with respect to distance learning anxiety. Furthermore, extraverted students reported a lower distance learning anxiety. Openness to experience was associated with high distance learning willingness. We conclude that evening types may benefit from distance learning more than other types.

Keywords: Personality; morningness-eveningness; distance learning; willingness; anxiety 


\section{Introduction}

One of today's most common learning applications is distance learning and it is continuing to become widespread. Distance learning (DL) is a learning application where students learn by using learning material and communication technology when instructors and students are separated by time and/or location (Moore \& Kearsley, 2005). For these reasons, DL students may have more self-directed, self-oriented, and independent learning habits and a higher level of information technology skills. In this respect most of the DL students are university students and they are older than face-toface students (Hunt, 2010; Mupinga, 2005; Tucker, 2003). So DL for adults is not a new application but DL in high schools has been growing in recent years (Rice, 2006). In the United States, approximately 700,000 elementary and secondary education students (1.1 \% of all K-12 students) were enrolled in DL in 2007 (Picciano \& Seaman, 2009). Open high school in Turkey was implemented in 1992 (Demiray \& Sağllk, 2003). Open high school programs or open education systems have the ability to offer quality education to a large number of students (Latchem, Özkul, Aydin, \& Mutlu, 2006). Open high school programs have become widespread over time and 1,548,158 K-12 students were enrolled in open high school and open vocational technical high school programs in Turkey in the 2011/12 year; 63,080 students were enrolled in open vocational technical high school programs from the Aegean and Marmara region of Turkey and a total of 235,257 students were enrolled in all regions of Turkey in the 2011/ 12 year (Ministry of National Education Turkey, 2012).

\section{K-12 Distance Learning}

There are different terminologies in the literature related to K-12 level DL. Some of them are K-12 DL, "virtual schools" and "cyber schools". We chose to use the K-12 DL concept in the study because of its widespread use. Many studies are addressing DL in adults, but there are limited studies of theK-12 level (Barbour \& Reeves, 2009; Cavanaugh, Barbour, \& Clark, 2009). With K-12 level application, DL began to cater for all age groups (adolescents and adults; Rice, 2006). At the K-12 level, although there are a limited number of articles, DL hasbeen studied mostly in the United States and Canada (Barbour \& Mulcahy, 2008; Picciano \& Seaman, 2009; Rice, 2006; Sheppard, 2009). Also especially the United States and Canada, K-12 level DL is increasing and spreading every day (Allen \& Seaman, 2013; Barbour, 2013; Demiray \& Sağllk, 2003; Smith, 2009). In developed countries such as USA and Canada, K-12 DL is used to provide the opportunity for students with learning disabilities. Other reasons in developing countries are students learning in different places and at different times, overcrowded classrooms, lack of quality teachers and school infrastructure (Barbour, 2013; Barbour \& Mulcahy, 2006; Cavanaugh \& Clark, 2007). In developing countries, such as Turkey, K-12 DL is used for economic, cultural, and social development (Moore $\&$ Kearsley, 2005). Another reason for the increase and spread of K-12 DL may be that students are more successful in DL than in face-to-face learning (Cavanaugh, 2001; Cavanaugh, Gillan, Hess \& Blomey, 2004; Rice, 2006). 
K-12 DL students are typically working adults and mostly women (Moore \& Kearsley, 2005), students with disabilities, and students from rural areas (Berman \& Tinker, 1997). In K-12 DL and other DL applications, the number of participants from rural areas is higher than from urban areas (Picciano \& Seaman, 2009). One of the reasons may be the more difficult access to schools and qualified personnel in rural areas. In addition, some studies stated that DL students from rural areas are at least equal or even more successful than those in the city center (Barbour \& Mulcahy, 2006, 2008; Sheppard, 2009). In this aspect, achievement is another reason why DL could be chosen by participants from rural areas.

DL (especially asynchronous DL) offers participants learning with their preferred speed, time and style (Roblyn, 1999). In this aspect, DL is developing critical and creative thinking, time management, problem solving skills, and independent learning habits (Barker \& Wendel, 2001). Despite these benefits, DL is not the most effective choice in all situations, especially not in novice students (Cavanaugh, Gillan, Kromrey, Hess, \& Blomeyer, 2005) and digital immigrants (Prenksy, 2001). When compared to face-toface learning, many students are not familiar with DL. These students, who faced DL for the first time, were defined as novices (see Cornacchione, Lawanto, Githens, \&J ohnson, 2012; Moore \& Kearsley, 2005). Conrad (2002) found that novice students express fear and anxiety when they start DL. Higher dropout rates may result from anxiety and may affect distance learning willingness (DLW; Cavanaugh, Barbour, \& Clark, 2009). Hara (2000) found that technical and communication skills and DL experience are important factors for a DL student's anxiety. Williams (2007) found that DL students prefer traditional face-to-face learning more than DL. On the contrary, Wang (2007) found that DL students were pleased with DL and willing to continue. For successful DL, a student's distance learning anxiety (DLA) and DLW are important variables (Horzum \& Çakır, 2012; Jegede \& Kirkwood, 1994) and may vary according to students' characteristics.

Although descriptive and media comparison studies have usually been done in DL literature (Bernard, Abrami, Lou, \& Borokhovski, 2004; Demiray \& Sağlık, 2003; McIsaac \& Gunawardena, 1996), students' individual differences have become a main topic of recent studies (Dillon \& Greene, 2003; Zawacki-Richter, 2009; ZawackiRichter, Bäcker, \&Vogt, 2009).

Chronotype or morningness-eveningness preference is one of these individual differences. Morningness-eveningness is an individual preference for a specific time of day for mental and physical performance (Adan, Archer, Hidalgo, Di Milia, Natale, \& Randler, 2012). There are small but significant gender differences with women scoring higher on morningness (Díaz-Morales \& Randler, 2008; Randler, 2007). Also, age effects can be found with young children being more morning oriented at the kindergarten age (Randler, Fontius, \& Vollmer, 2012) and a strong tendency towards eveningness during adolescence (Carskadon, Vieira, \& Acebo, 1993; Collado, DíazMorales, Escribano, Delgado, \& Randler, 2012). At the end of adolescence, a turn back 
to morningness occurs (Roenneberg, Kuehnle, Pramstaller, Ricken, Havel, Guth, \& Merrow, 2004) and people become progressively more morning oriented towards their later years of life (Randler \& Bausback, 2010). Despite these common general patterns, significant inter-individual differences in chronotype remain throughout the lifespan.

One advantage of DL is the independent time management so students can learn at their optimal time of day. This is in strong contrast to the usual early morning schedules at school (Hurd, 2007). Evening type students with regularly scheduled school learning have more problems (emotional problems, timing of sleep, learning success, etc.; Gau, Shang, Merikangas, Chiu, Soong, \& Cheng, 2007). Recent research showed that chronotype had a significant influence on school and university achievement (Beşoluk, 2011; Fabbri, Antonietti, Giorgetti, Tonetti, \& Natale, 2007; Randler \& Frech 2006, 2009) with earlier chronotypes being at an advantage. Thus eveningness should be related to DLW.

Chronotype is also related to personality factors as measured by different inventories (for an overview see Tsaousis, 2010 and Adan et al., 2012). In the current literature on DL, two of the most widely recognized and applied personality models are the MyersBriggs (MBTI) and the Big Five personality model (BIG-5). MBTI profiles are known to have strong implications on learning style, and BIG-5 represents the dominant conceptualization of personality in the current literature (Kim, 2011; Kim \&Schniederjans, 2004). Research on personality and chronotype indicated that eveningness is related to extraversion, impulsivity, novelty seeking, depressive symptomatology as well as openness and, to smaller extent, psychoticism (psychopathology) while morningness is related to conscientiousness, agreeableness, persistence, and emotional stability (see Adan et al., 2012; Tsaousis, 2010).

There is only limited research onchronotype and other personality dimensions in DL. Individual differences in personality influence outcomes and experiences of DL. For example, students with lower conscientiousness failed their courses more often (Santo, 2001) and high emotional stability was related to persistence (Kemp, 2002). High introversion was related to preference and participation in DL (Moore \& Kearsley, 2005). Anxiety scores of the DL students are relatively moderate or higher and anxiety levels didn’t change significantly overtime (Bolliger \& Halupa, 2012; MacGregor, 2002).

Önder, Horzum, and Beşoluk (2012) worked with face-to-face and blended learning students. They noticed the importance of the synchronicity between learning time and circadian preference. In their research it was found that students' performance was enhanced when teaching was performed in sync with students' chronotype. Evening types in face-to-face learning students expressed a higher DLW and they chose DL lessons more often than morning types (J ovanovski \& Bassili, 2007). Horzum, Önder, and Beşoluk (2014) found no difference in online learning students' achievement according to chronotype. Furthermore, Luo, Pan, Choi, Mellish, and Strobel (2011) found that students' chronotype affected their individual daily time schedules for DL. 
Studies on cognitive abilities and performance showed evidence for a synchrony effect, that is, evening types should prefer and perform better in later lessons and morning types should prefer and perform better in earlier lessons (Goldstein, Hahn, Hasher, Wiprzycka, \&Zelazo, 2007).

Previous research did not investigate the influence of personality and individual differences (chronotype and BIG-5) on DLA and DLW. The aim of this research is to investigate differences of the students' DLA and DLW according to age, gender, occupation, and personality (chronotype and BIG-5). We hypothesize that eveningness is associated with higher DLW.

\section{Method}

The research was based on quantitative paper-and-pencil survey methodology. Students filled out self-administered questionnaires. Data were collected by hand.

\section{Participants}

Participants voluntarily completed a questionnaire in the 2012 academic cycle. These participants were purposively sampled from Vocational Open High Schools (VOHS). The reason for the selection of students in the VOHS is that it is the most widely spread and most preferred application in the K-12 level DL in Turkey (Horzum, 2007). Seven hundred and sixty-nine VOHS students participated, 408 (53.1\%) were females. Age ranged from 14 to 44 years, 580 (75.4\%) students were between 14-18 years old, and 189 (24.6\%) students were between 19 and 44 years; the mean age was $17.78( \pm 2.29)$ years. Two hundred and seventy-nine (36.3\%) were employed (part time students) and 490 (63.7\%) were unemployed (full time students). Two hundred and forty-two (31.5\%) were from the Aegean and 527 (68.5\%) from the Marmara region of Turkey. These two regions of Turkey are comparable for the rise of the sun and sunlight proportion.These two regions were selected because they share a similar longitude and similar development level.

\section{VOHS System in Turkey}

The VOHS education system lasts at least fouracademic years and eightsemesters (an academic year consists of two semesters). If one of the student's mean year-end reaches45 points and higher, theypassthe course successfully. Students who have successfully completed their course acquire credits.

There is no age restriction in VOHS. People of all ages who graduated from elementary school or dropped out from high school can apply to VOHS. In these programs, common (general cultural) field and elective courses are included. Students in the VOHS take 
mandatory (field) courses with face-to-face, common (general cultural) and elective courses with DL (for detailed information see http:// maol.meb.gov.tr/ ).

Field courses consisting of 130 credits are presented by face-to-face learning. In addition, common (general cultural) and elective courses consisting of 110 credits are presented withDL. Students who completed the total 240 credits will graduate. Common and elective courses are placed in the first year of the VOHS system. Field, common and elective courses are placed in the second, third and fourth year of the VOHS system. In this respect, DL takes place in the first year of the system. From the second year, while field courses occur with face-to-face training, common and elective courses still have to be taken with DL.

VOHS students must take courses that are determined by the Ministry of Education in order to graduate from school. These students are required to take the exam with all common (general cultural) and field courses. Also they are required to complete the credits for graduation. If they fail, they have to repeat the course. If a student fails an elective course, he/ she may repeat that course or choose another elective course (see http://maol.meb.gov.tr/html_files/derslisteleri.html).

VOHS course timetables and syllabuses can't be changed and students can't take courses prior to the related term. Books and lecture notes of DL courses are available free of charge. Students can access and use those books and notes in electronic format on the internet whenever they need to (see http://maol.meb.gov.tr/html_files/derskitaplari.html and http://hbogm.meb.gov.tr/ www/ acik-ogretim-lisesi-ders-notlari/icerik/56). There are also internet TV and radio broadcasts on the website to serve as supportive course materials (http:/ / internettv.meb.gov.tr/index.asp).

\section{Instruments}

\section{Composite Scale of Morningness (CSM)}

Students' morningness-eveningness preferences were measured with the Composite Scale of Morningness (CSM) which was developed by Smith, Reilly, and Midkiff (1989). The CSM is composed of 13Likert scale items and the total score varies from a minimum of 13 to a maximum of 55 with high scores reflecting high morningness. The scale is used in many different countries and shows good psychometric properties and convergent validity with psychometric measures (Caci, Deschaux, Adan, \& Natale, 2009; Randler, 2009). The scale was adapted into Turkish by Önder, Beşoluk, and Horzum (2013). Cronbach's alpha coefficients of the CSM were reported as .73 in a high school sample. The internal consistency coefficient of the scale was .64 in this study. 


\section{Big Five Inventory (BIG-5)}

Students' personality was measured using the BIG-5. In this study the BIG-5 is used in its 10-item short version. Short questionnaires can be good measurements when time is constrained (Burisch, 1998). The scale contains 10 items on a five-point Likert scale. It was developed by Gosling, Rentfrow, and Swann (2003) and adapted into Turkish by Günel (2010). The scale consists of five dimensions (agreeableness, conscientiousness, extraversion, neuroticism [the opposite of emotional stability], and openness) with two items for each dimension. The internal consistency (Cronbach's alpha) of the dimensions ranged from .70 to .89 .

\section{Distance Learning Willingness Scale (DLW)}

The DLW instrument was developed by Horzum and Çakır (2012). The DLW consists of two factors and 10 items and it is in the form of a five-point Likert type scale. The total score varies from a minimum of 10 to a maximum of 50, indicating high DLW. Cronbach's alpha coefficients of the CSM were reported as .90. The internal consistency of the present study was .86.

\section{Distance Learning Anxiety Scale (DLA)}

Students' anxiety related to DL was measured using the DLA scale, developed by Horzum and Çakır (2012). The DLA consists of six items and it is in the form of a fivepoint Likert scale. The total score varies from a minimum of 6 to a maximum of 30, indicating high DLA. The internal consistency coefficient of the scale was .90. The internal consistency coefficient of the scale was $.87 \mathrm{in}$ this study.

\section{Procedure}

Permission for the conduct was obtained from the National Education Directorships. Participation was anonymous and voluntary, and there was a guarantee of confidentiality. For the statistical analyses, Pearson correlation coefficients and MANOVA (generalized linear model, GLM) were utilized to determine the relationships and differences between variables. These analyses were performed via SPSS 20.

\section{Results}

Participants' DLW scores ranged from 6 to 30 ( $\bar{X} \pm$ SD; $29.42 \pm 9.20$ ), DLA scores ranged from 6 to 30 ( $\bar{X} \pm \mathrm{SD} ; 15.81 \pm 6.14$ ), and morningness-eveningness scores ranged from 15 to 50 ( $\bar{X} \pm \mathrm{SD} ; 35.75 \pm 5.54$ ). Concerning BIG-5 factors mean scores $( \pm \mathrm{SD})$ were $3.27( \pm 1.06)$ for extraversion, $3.84( \pm 0.89)$ for agreeableness, $3.77( \pm 0.96)$ 
for conscientiousness, $2.89( \pm 0.92)$ for neuroticism and, finally, $3.23( \pm 0.91)$ for openness to experience. In our participants, neuroticism scored lowest and agreeableness highest.

Female VOHS students reported a lower willingness ( $\bar{X} \pm \mathrm{SE} 2.84 \pm .048$ ) than male students $(3.03 \pm .049)$. Later chronotypes reported a higher willingness $(r=-.110, p=$ .002). This result showed that evening type students have higher willingness to DL. Older VOHS students showed a higher willingness to DL ( $r=.096, p=.008)$ and a lower anxiety $(r=-.065, p=.074)$, extraverted students reported a lower anxiety $(r=-.153, p$ $<.001$; Table 1).

Table 1

Correlations between Study Variables

\begin{tabular}{lrrrrrrrr}
\hline & 2 & 3 & 4 & 5 & 6 & 7 & 8 & 9 \\
\hline 1 DLW & -.038 & $* * .096$ & $* *_{-} .110$ & .060 & -.039 & .020 & -.028 & $* * .101$ \\
2 DLA & & .065 & -.059 & $* *_{-} .153$ & $*_{-} .090$ & $* *-.095$ & $* .072$ & -.057 \\
3 Age & & & .051 & .000 & $* *_{-} .106$ & -.012 & -.044 & .062 \\
4 CSM & & & & -.022 & $* * .155$ & $* * .102$ & $*_{-} .088$ & -.063 \\
5 Extraversion & & & & & .043 & $* * .256$ & $* *_{-} .114$ & $* * .173$ \\
6 Agreeableness & & & & & & $* * .305$ & -.032 & -.010 \\
7 Conscientiousness & & & & & & -.059 & $* * .097$ \\
8Emotional Stability & & & & & & & .017 \\
9 Openness to Experiences & & & & & & & - \\
\hline
\end{tabular}

Asterisks indicate significant correlations: $* \mathrm{p}<.050, * * \mathrm{p}<.010 ; 1$, DLW $=$ Distance learning willingness; 2, DLA = Distance learning anxiety; 4, CSM = Composite Scale of Morningness: $13=$ extreme eveningness to $55=$ extreme morningness; 5 to 9, Big-Five dimensions.

We found significant main effects in the multivariate GLM (MANOVA) of gender [ $\lambda=$ $\left..989, \mathrm{~F}(2,758)=4.068, \mathrm{p}=.017, \eta^{2}=.011\right]$, CSM score $[\lambda=.988, \mathrm{~F}(2,758)=4.471, \mathrm{p}=$ $\left..012, \eta^{2}=.012\right]$, age $\left[\lambda=.987, \mathrm{~F}(2,758)=4.869, \mathrm{p}=.008, \eta^{2}=.013\right]$ and extraversion $\left[\lambda=.982, F(2,758)=6.760, p=.050, \eta^{2}=.018\right]$ on willingness and anxiety, but not of occupation (yes $/ \mathrm{no})[\lambda=.998, \mathrm{~F}(2,758)=.636, \mathrm{p}=.530]$, agreeableness $[\lambda=.995, \mathrm{~F}(2$, $758)=1.737, \mathrm{p}=.177]$, conscientiousness $[\lambda=.999, \mathrm{~F}(2,758)=.513, \mathrm{p}=.599]$ and emotional stability $[\lambda=.997, F(2,758)=1.154, p=.316]$. Openness tended to have a significant influence $[\lambda=.992, \mathrm{~F}(2,758)=2.906, \mathrm{p}=.055]$.

Gender was a significant predictor of willingness but not of anxiety, CSM was associated with willingness. Age showed an effect on willingness and a trend on anxiety, extraversion was associated with anxiety, and openness was associated with willingness (Table 2). 
Table 2

General Linear Model, Univariate Statistic Results

\begin{tabular}{lllll}
\hline & Dependent Variable & $\mathrm{F}$ & $\mathrm{p}$ & $\eta^{2}$ \\
\hline \multirow{2}{*}{ Gender (male/ female) } & DLW & 8.138 & .004 & .011 \\
& DLA & .000 & .984 & .000 \\
Age & DLW & 6.201 & .013 & .008 \\
& DLA & 3.807 & .051 & .005 \\
Occupation (yes/no) & DLW & .847 & .358 & .001 \\
& DLA & .460 & .498 & .001 \\
Chronotype (CSM) & DLW & 7.526 & .006 & .010 \\
BIG-5 Extraversion & DLA & 1.255 & .263 & .002 \\
& DLW & .984 & .321 & .001 \\
BIG-5 Agreeableness & DLA & 12.736 & $<001$ & .017 \\
\multirow{3}{*}{ BIG-5 Conscientiousness } & DLW & .007 & .935 & .000 \\
& DLA & 3.461 & .063 & .005 \\
BIG-5 Emotional Stability & DLW & .536 & .464 & .001 \\
& DLA & .520 & .471 & .001 \\
BIG-5 Openness & DLW & .630 & .428 & .001 \\
& DLA & 1.736 & .188 & .002 \\
& DLW & 5.157 & .023 & .007 \\
& DLA & .766 & .382 & .001 \\
\hline
\end{tabular}

$\mathrm{CSM}=$ Composite Scale of Morningness; DLW = Distance learning willingness; DLA = Distance learning anxiety.

\section{Discussion}

Until recently, research on DL mostly focused on achievement, attitude, and satisfaction (Moore \& Kearsley, 2005; Zawacki-Richter, Bäcker, \& Vogt, 2009). However, there is limited research on DLW and DLA (Hara, 2000; Horzum \& Çakır, 2012; Hurd, 2007; J egede \& Kirkwood, 1994). Moreover, studies on individual differences (especially chronotype and BIG-5) in DL also have just begun to rise.

Evening orientation was related to a higher DLW, which remained significant after controlling for personality in the linear model. Similarly, evening type students had higher DLW, a finding that has been previously proposed by Jovanovski and Bassili (2007). These findings indicated that a DL program can present learning environments that are better suited to individual differences (Moore \& Kearsley, 2005), especially of the late chronotype. So, for evening type students, DL is perceived as the better option. Asynchronous DL is carried out in VOHS. One explanation of these results may lie in the nature of asynchronous DL. In DL programs, all students may set the schedule themselves, yet are able to access learning material and lessons from anywhere and anytime and learn at their own pace. Moreover, it was found that students' chronotype affected the choice of learning time in DL (Luo et al., 2011). Evening type students, who have more problems (emotional problems, timing of sleep, learning success, etc.) with regular scheduled school learning (Gau et al., 2007) because of early school schedules 
(Beşoluk, 2011), may prefer DL environments. An interesting question might be to compare individual learning processes in DL and in scheduled school programs.

DLA was unrelated to morningness-eveningness. As anxiety was unrelated to chronotype, DL should benefit all chronotypes equally with the advantage of working/performing at one's own best time. Therefore we encourage educational institutions to implement DL programs.

Moreover, extraverted students reported lower DLA. Extraverted students have a tendency to be sociable, talkative, active, and ambitious (Kim, 2011), so they reported lower anxiety. Open-minded students reported a higher DLW. This finding is consistent with the literature: Santo (2001) found that students with higher scores on openness to experience also express positive opinions of DL and they learn effectively when taking DL (Kim \& Schniederjans, 2004).

Furthermore, this study showed that age has an effect on DLW. Older students may prefer DL because most of the older students are married and work while studying. Because they work or take care of children, it is difficult to participate in face-to-face lessons, and DL might be the better opportunity to study. Therefore, their DLW is higher. Consistent with the results of our study, Hurd (2007) found that older students prefer DL since they are learning within the context of family and work, and they need to fit learning into their time schedule and therefore prefer to study at their own pace. However, it was found that age was also associated with anxiety. This finding is consistent with Conrad (2002). Most of the older people haven't enough information technology skills (Prenksy, 2001) to benefit from DL. In DL, students have to handle some technological devices for learning. In conclusion, this anxiety may result from older students' lack of technological skills.

In this study we found that DLA of students did not differ with respect to gender. Consistent with the results of this study, Jegede and Kirkwood (1994) found no significant differences in students' DLA according to gender. However, it was found that women have lower DLW than men. Women who successfully perform in a face-to-face learning environment (Beşoluk, 2011) want to remain in this familiar environment and not turn towards DL.

Our study has several limitations. One of them is that participants were VOHS students. In order to obtain a more generalized result for all high school students, similar studies are needed from open high school or open secondary school students. 720 students participated in the study. For more generalized results further research should be done with more participants. Another limitation is related to the data collection process. We used only quantitative instruments. One of the problems in findings related to DL is the use of quantitative methods (Bernard, Abrami, Lou, \& Borokhovski, 2004). In addition, to increase the validity of the data, some other measures (qualitative methods) should be obtained, such as observation, interview, document analysis, and so on. 
Furthermore, since participation was voluntary, the sample suffers from self-selection. Asynchronous DL is carried out in VOHS. Also similar studies can be done on synchronous DL applications or comparable studies can be done on synchronous and asynchronous applications.

In conclusion, our study contributes to the knowledge about differences in DLW and DLA according to circadian types and personality. Future work should further investigate acceptance of DL applications in relation to circadian type and personality. 


\section{References}

Adan, A., Archer, S. N., Hidalgo, M. P., Di Milia, L., Natale V., \& Randler, C. (2012). Circadian typology: A comprehensive review. Chronobiology International, 29(9), 1153-1175.

Allen, I. E., \& Seaman, J . (2013). Grade change - tracking online education in the United States. Retrieved J uly 05, 2014 from http:// www.onlinelearningsurvey.com/reports/gradechange.pdf

Barbour, M. K., \& Mulcahy, D. (2006). An inquiry into retention and achievement differences in campus based and web based AP courses. Rural Educator, 27(3), 8-12.

Barbour, M. K., \& Mulcahy, D. (2008). How are they doing? Examining student achievement in virtual schooling. Education in Rural Australia, 18(2), 63-74.

Barbour, M. K., \& Reeves, T. C. (2009). The reality of virtual schools: A review of the literature. Computers \& Education, 52(2), 402-416.

Barbour, M. K. (2013). State of the nation: K- 12 online learning in Canada. Retrieved J uly 05, 2014, from http:// www.openschool.bc.ca/pdfs/state_of_nation2013.pdf

Barker, K., \&Wendel, T. (2001).E-learning: Studying Canada’s virtual secondary schools. Society for the Advancement of Excellence in Education, Research Series\# 8.Retrieved July 05, 2014, from http://www.saee.ca/publications/A_006_FFA_MID.php.

Berman, S., \& Tinker, R. (1997). The world's the limit in the virtual high school. Educational Leadership, 55(3), 52-54.

Bernard, R., Abrami, P., Lou, Y., \& Borokhovski, E. (2004). A methodological morass? How we can improve quantitative research in distance education. Distance Education, 25(2), 175-198.

Beşoluk, Ş. (2011).Morningness-eveningness preferences and university entrance examination scores of high school student. Personality and Individual Differences, 50(2), 248-252.

Bolliger, D. U., \& Halupa, C. (2012). Student perceptions of satisfaction and anxiety in an online doctoral program. Distance Education, 33(1), 81-98. 
Burisch, M. (1998). Test length and validity revisited. European J ournal of Personality, 11, 303-315.

Caci, H., Deschaux, O., Adan, A., \& Natale, V. (2009). Comparing three morningness scales: Age and gender effects, structure and cut-off criteria. Sleep Medicine, 10, 240-245.

Carskadon, M. A., Vieira, C., \&Acebo, C. (1993). Associations between puberty and delayed phase preference. Sleep, 16, 258-262.

Cavanaugh, C. (2001). The effectiveness of interactive distance education technologies in K-12 learning: A meta-analysis. International J ournal of Educational Telecommunications, 7(1), 73-88.

Cavanaugh, C. S., Barbour, M. K., \& Clark, T. (2009).Research and practice in K-12 online learning: A review of open access literature. International Review of Research in Open and Distance Learning, 10(1), 1-22.

Cavanaugh, C. \& Clark, T. (2007).The landscape of K-12 online learning. In Cavanaugh, C. \& Blomeyer, B. (Eds.), What works in K-12 online learning. Eugene, OR: International Society for Technology in Education.

Cavanaugh, C., Gillan, K. J ., Kromrey, J ., Hess, M., \&Blomeyer, R. (2004).The effects of distance education on K-12 student outcomes: A meta-analysis. Naperville, IL: Learning Point Associates. Retrieved November 13, 2012 from http:// www.ncrel.org/ tech/ distance/ k12distance.pdf

Collado, M. J ., Díaz-Morales, J . F., Escribano, C., Delgado, P., \&Randler, C. (2012). Morningness-Eveningness and sleep habits among adolescents: Age and gender effects. Psicothema, 24, 410-415.

Conrad, D. L. (2002). Engagement, excitement, anxiety, and fear: Learners' experiences of starting an online course. American J ournal of Distance Education, 16, 205226.

Cornacchione, E. B., Lawanto, O., Githens, R. P., \&J ohnson, S. D. (2012). The role of students' professional experience in online learning: Analysis of asynchronous participation. MERLOTJ ournal of Online Learning and Teaching, 8(2). Retrieved from http://jolt.merlot.org/vol8no2/ cornacchione_0612.pdf

Demiray, U., \& Sağlık, M. (2003). General evaluation on the researches which are conducted on open education faculty and open high school applications. The Turkish Online J ournal of Educational Technology, 2(4), 50-59. 
Díaz-Morales, J . F., \& Randler, C. (2008). Morningness- eveningness among German and Spanish adolescents 12-18 years. European Psychologist, 13, 214- 221.

Dillon, C., \& Greene, B. (2003). Learner differences in distance learning: Finding differences that matter. In M. G. Moore \&W. G. Anderson (Eds.), Handbook of distance education (pp. 235-244). Mahwah, NJ : Lawrence Erlbaum Associates.

Fabbri, M., Antonietti, A., Giorgetti, M., Tonetti, L., \& Natale, V. (2007). Circadian typology and style of thinking differences. Learning and Individual Differences, 17, 175-180.

Fulton, K., \& Kober, N. (2002). Preserving principles of public education in an online world. Washington, DC: Center on Education Policy. Retrieved November, 28, 2011, from http:// www.ctredpol.org/democracypublicschools/preserving principles online world full.pdf

Gau, S. S.-F., Shang, C.-Y., Merikangas, K. R., Chiu, Y.-N., Soong, W.-T., \& Cheng, A. T.A. (2007). Association between morningness-eveningness and behavioral/ emotional problems among adolescents. J ournal of Biological Rhythms, 22, 268-274.

Goldstein, D., Hahn, C. S., Hasher, L., Wiprzycka, U. J ., \&Zelazo, P. D. (2007).Time of day, intellectual performance, and behavioral problems in morning versus evening type adolescents: Is there a synchrony effect? Personality and Individual Differences, 42, 431-440.

Gosling, S. D., Rentfrow, P. J ., \& Swann Jr, W. B. (2003). A very brief measure of the Big-Five personality domains. J ournal of Research in Personality, 37, 504-528.

Günel, Ö. D. (2010). Mobbing in organizations and a research on mobbing victims' personality characteristics. DokuzEylül University Social Science Institute J ournal, 12(3), 37-65.

Hara, N. (2000). Student distress in a web based distance education course. Information, Communication \& Society, 3(4), 557-579.

Horzum, M. B., \&Çakır, Ö. (2012). Structural equation modelling in readiness, willingness and anxiety of secondary school students about the distance learning. Cyprus International Conference On Educational Research Cy-Icer 2012, O8-11 FEBRUARY 2012, Middle East Technical University Northern Cyprus Campus, Northern Cyprus. 
Horzum, M. B., Önder, İ., \& Beşoluk, Ş. (2014). Chronotype and academic achievement among online learning students. Learning and Individual Differences, 30, 106111.

Horzum, M.B. (2007). The effect of transactional distance on students' achievement, satisfaction and self efficacy in internet based education (Unpublished $\mathrm{PhD}$ thesis). Ankara: Ankara University Educational Science institute.

Hunt, S. (2010). Profile of the UWI distance learners:The implications for online curriculum development, teaching and learning at the university. Turkish Online J ournal of Distance Education-TOJ DE,11(3). Retrieved November 13, 2012 from https:// tojde.anadolu.edu.tr/ tojde39/articles/article 4.htm.

Hurd, S. (2007). Anxiety and non-anxiety in a distance language learning environment: The distance factor as a modifying influence. System, 35, 487- 508.

J egede, O. J ., \& Kirkwood, J . (1994). Students' anxiety in learning through distance education. Distance Education, 15(2), 279-290.

J ovanovski, D., \& Bassili, J . N. (2007).The relationship between morningnesseveningness preference and online learning. Biological Rhythm Research, 38(5), 355-365.

Kemp, W. C. (2002). Persistence of adult learners in distance education. American J ournal of Distance Education, 16(2), 6581.

Kim, E. B. (2011). Student Personality and learning outcomes in e-learning: An introduction to empirical research. Ed: S.B. Eom \&J .B. Arbaugh. Student satisfaction and learning outcomes in e-learning: An introduction to empirical research (pp. 294-315). USA: IGI Global.

Kim, E. B., \& Schniederjans, M. (2004). The role of personality in Web-based distance education course. Communications of the ACM, 47(3), 95- 98.

Latchem, C., Özkul, A. E., Aydin, C. H., \& Mutlu, M. E. (2006). The open education system, Anadolu University, Turkey: e-transformation in a mega-university. Open Learning, 21(3), 221- 235.

Luo, Y., Pan, R. C., Choi, J . H., Mellish, L., \& Strobel, J . (2011).Why choose online learning: Relationship of existing factors and chronobiology. J ournal of Educational Computing Research, 45(4), 379-397. 
MacGregor, C. J . (2002). Personality differences between online and facetoface students. The J ournal of Continuing Higher Education, 50(3), 14-23.

McIsaac, M. S., \& Gunawardena, C. N. (1996). Distance education. In D.H. J onassen (Ed.), Handbook of research for educational communications and technology: A project of the association for educational communications and technology (pp. 403-437). New York: Simon\&Schuster Macmillan.

Ministry of National Education, Turkey (2012). National Education Statistics Formal Education 2011-2012. Retrieved from http://sgb.meb.gov.tr/meb iys dosyalar/2012_12/06021046_meb istatistikle ri orgun egitim 2011 2012.pdfaccessed 14.1.2013

Moore, M., \&Kearsley, G. (2005). Distance education: A systems view (2nded.). Belmont, CA: Wadsworth.

Mupinga, D. M. (2005). Distance education in high schools benefits, challenges, and suggestions. The Clearing House, 78(3), 105-108.

Önder, İ., Beşoluk, Ş., \& Horzum, M. B. (2013). Psychometric properties of the Turkish version of the composite scale of morningness in high school and university students. The Spanish J ournal of Psychology, 16(E67), 1-10.

Önder, İ.,Horzum, M. B., \& Beşoluk, Ş. (2012). Chronotype, learning approach, type/ time of instruction and academic achievement of the university students. In L. Golovkin\&A. Maliszkewicz (Eds.), Circadian rhythms: Biology, cognition and disorders. Nova Science Publishers.

Picciano, A. G., \& Seaman, J. (2009).K- 12 onlinelearning: A 2008 follow-up of the survey of U.S. school district administrators. Needham, MA: Sloan Consortium. Retrieved, November 13, 2012 from http:// www.sloanc.org/publications/survey/ pdf/K-12 Online_Learning.pdf

Prenksy, M. (2001). Digital natives, digital immigrants. On the Horizon, 9(5), 1- 6.

Randler, C. (2007). Gender differences in morningness- eveningness assessed by self report questionnaires: A meta-analysis. Personality and Individual Differences, 43, $1667-1675$.

Randler, C. (2009). Validation of the full and reduced Composite Scale of Morningness. Biological Rhythm Research, 40, 413-423. 
Randler, C., \& Bausback, V. (2010).Morningness-eveningness in women around the transition through menopause and its relationship with climacteric complaints. Biological Rhythm Research, 41, 415-431.

Randler, C., \& Frech, D. (2006). Correlation between morningness- eveningness and final school leaving exams. Biological Rhythm Research, 37, 233- 239.

Randler, C., \&Frech, D. (2009). Young people's time-of-day preferences affect their school performance. J ournal of Youth Studies, 12, 653- 667.

Randler, C., Fontius, I., \& Vollmer, C. (2012).Delayed weekend sleep pattern in German infants and children aged 0-6 years. Biological Rhythm Research, 43, 225-234.

Rice, K. L. (2006). A comprehensive look at distance education in the K-12 context. J ournal of Research on Technology in Education, 38(4), 425-448.

Roblyer, M. D. (1999). Is choice important in distance learning? A study of student motives for taking internet-based courses at the high school and community college levels. J ournal of Research on Computing in Education, 32(1), 157-171.

Roenneberg, T., Kuehnle, T., Pramstaller, P. P., Ricken, J ., Havel, M., Guth, A., \& Merrow, M. (2004). A marker for the end of adolescence.Current Biology, 14, 1038-1039.

Santo, S. A. (2001). Virtual learning, personality, and learning styles (Unpublished doctoral dissertation). University of Virginia, Charlottesville, Virginia.

Sheppard, P. (2009). Determining the effectiveness of web-based distance education in mitigating the rural-urban achievement gap (Unpublished master's thesis). St. J ohn's, Newfoundland and Labrador, Canada: Memorial University of Newfoundland.

Smith, C. S., Reily, C., \& Midkiff, K. (1989).Evaluation of three circadian rhythm questionnaires with suggestions for an improved measure of morningness. J ournal of Applied Psychology, 74, 728 - 738.

Smith, S. (2009). High school students perceptions of distance learning (Ph.D. dissertation). Walden University, United States.

Tsaousis, I. (2010) Circadian preferences and personality traits: A meta-analysis. European J ournal of Personality, 24, 356-373. 
Tucker, S. Y. (2003). A portrait of distance learners in higher education.Turkish Online J ournal of Distance Education, 4 (3). Retrieved November 13, 2012 from http://tojde.anadolu.edu.tr/tojde11/articles/tucker.htm.

Wang, Y. (2007). Faculty and student perceptions of Internet-based distance education (Ed. D. dissertation). Texas A\&M University, Kingsville, United States.

Williams, D. (2007). Online learning: Student perceptions of variables that impact learning performance (Ph.D. dissertation). The University of Nebraska, Lincoln, United States.

Zawacki-Richter, O. (2009). Research areas in distance education: A delphi study. International Review of Research in Open and Distance Learning, 10(3), 1-17.

Zawacki-Richter, O., Bäcker, E. M., \&Vogt, S. (2009). Review of distance education research (2000 to 2008): Analysis of research areas, methods, and authorship patterns. International Review of Research in Open and Distance Learning, 10(6), 21-50.

(C) Randler, Horzum, Vollmer

\section{Athabasca University $\mathbf{Z}$}

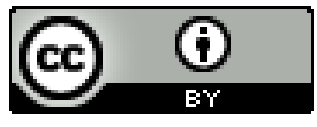

This work is licensed under a Creative Commons Attribution 4.0 International License. 